\title{
Insertion Reactions of Metal Carbonyl Anions with Methyl Formate in the Gas Phase as Revealed by ${ }^{13} \mathrm{C}$ - and D-Labeling
}

\author{
Klaas Jan van den Berg, Steen Ingemann, and Nico M. M. Nibbering \\ Institute of Mass Spectrometry, University of Amsterdam, Amsterdam, The Netherlands
}

Ian K. Gregor

School of Chemistry, University of New South Wales, Kensington, Australia

The gas-phase reactions of coordinatively unsaturated metal carbonyl anions $\left(\mathrm{M}(\mathrm{CO})_{n}^{-}\right.$, $\mathrm{M}=\mathrm{Cr}, \mathrm{Mn}, \mathrm{Fe}, \mathrm{Co} ; \mathrm{n}=0-3$ and $\left.\mathrm{Co}(\mathrm{CO})_{n} \mathrm{NO}^{-}, \mathrm{n}=0-2\right)$ with unlabeled and $\mathrm{D}$ - and ${ }^{13} \mathrm{C}$-labeled methyl formate have been studied with Fourier transform ion cyclotron resonance mass spectrometry. The reactions proceed in most instances by loss of one or more CO molecules from the collision complex. In the reactions of the dicarbonyl and tricarbonyl anions with $\mathrm{H}^{13} \mathrm{COOCH}_{3}$, part of the eliminated carbon monoxide molecules contain the label revealing the occurrence of initial insertion of the metal center into the bonds adjacent to the carbonyl function of the substrate with formation of five- or six-coordinate intermediates, respectively. In addition, the $\mathrm{Mn}(\mathrm{CO})_{3}^{-}, \mathrm{Fe}(\mathrm{CO})_{2}^{-}$, and $\mathrm{Co}(\mathrm{CO})_{2}^{-}$ions react by the loss of methanol and a $\left[\mathrm{C}_{1} \mathrm{H}_{2}, \mathrm{O}\right]$ neutral species. The $\mathrm{D}$ - and ${ }^{13} \mathrm{C}$-labeling show that methanol is expelled in a reductive elimination from a five- or six-coordinate species, whereas the $\left[\mathrm{C}, \mathrm{H}_{2}, \mathrm{O}\right]$ loss is a more complex process possibly involving the competing losses of formaldehyde and $\mathrm{CO}+\mathrm{H}_{2}$. In the reaction of $\mathrm{Fe}(\mathrm{CO})_{3}^{-}$with $\mathrm{H}^{13} \mathrm{COOCH}_{3}$, a facile consecutive exchange of all three $\mathrm{CO}$ ligands of the reactant ion for ${ }^{13} \mathrm{CO}$ is observed. This novel reaction appears to involve initial insertion into the $\mathrm{H}^{13} \mathrm{CO}-\mathrm{OCH}_{3}$-bond followed by facile hydrogen shifts from the formyl ligand to a CO ligand prior to the loss of unlabeled methyl formate. (J Am Soc Mass Spectrom 1994, 5, 525-536)

$\mathrm{T}$ Iransition metal carbonyl compounds have been used as catalysts in a variety of important industrial processes throughout this century [1,2], and the mechanisms of many of these processes have been investigated and elucidated since. Abundantly available, for example, as a product from the combustion of coal in the presence of steam, carbon monoxide is one of the most important ligands in transition metal chemistry and a key substrate in well-known (mostly homogeneous) catalytic processes such as the Reppe reaction, the Fischer-Tropsch reaction, Monsanto's acetic acid process, the oxo (or hydroformylation) reaction, and the water gas shift reaction $[1,2]$. One of the central steps in these complex catalytic reactions is migration of an alkyl group or hydrido ligand from a metal center to a coordinated $\mathrm{CO}$ molecule with the attendant formation of an acyl of formyl ligand, respectively (eq 1):

$$
\mathrm{R}-\mathrm{M}-\mathrm{C}=\mathrm{O} \rightarrow \mathrm{M}-\mathrm{C}(\mathrm{O})-\mathrm{R}
$$

Address reprint requests to Nico M. M. Nibbering, Institute of Mass Spectrometry, University of Amsterdam, Nieuwe Achtergracht 129, 1018 WS Amsterdam, The Netherlands.
Other steps in these processes involve typical organometallic reactions such as oxidative addition, reductive elimination, ligand addition or substitution [2], and insertion of a metal center in a formyl group, that is the reverse of the reaction in eq 1 . In principle, these fundamental reactions can be studied in the gas phase in the absence of solvation phenomena. In fact, a large number of studies have documented that positive [3] as well as negative $[4,5]$ transition metal ions can be generated in the gas phase, thereby allowing their unimolecular or bimolecular chemistry to be studied by a variety of mass spectrometric methods with the purpose of obtaining fundamental insights into these reactions. The study of the gas-phase chemistry of metal ions has also provided thermochemical data such as electron affinities of neutral metal species and metal-ligand bond strengths of various transition metal-containing ions [6-9].

The majority of the published studies of electron deficient metal carbonyl anions is concerned with the reactivity of only one or two jons with several selected substrates. In a few instances, however, the reactivity of a broader range of metal-containing anions has been studied as exemplified by the drift-cell ion cyclotron 
resonance (ICR) studies of McElvany and Allison [10, 11]. Recently, we compared the reactivity and relative reaction rates of the $\mathrm{Cr}(\mathrm{CO})_{\mathrm{x}}^{-}(\mathrm{x}=0,2-5), \mathrm{Mn}(\mathrm{CO})_{\mathrm{x}}^{-}$ $(x=1-5)$, and $\mathrm{Fe}(\mathrm{CO})_{x}^{-}(x=0-4)$ ions with heptane, methanol, and water [12]. In particular, the $\mathrm{Cr}(\mathrm{CO})_{3}^{-}$ (13 valence electrons), $\mathrm{Mn}(\mathrm{CO})_{3}^{-}$(14 electrons), and $\mathrm{Fe}(\mathrm{CO})_{2}^{-}$(13 electrons) ions displayed a rich chemistry in their reactions with methanol, which involved competing initial $\mathrm{O}-\mathrm{H}$ and $\mathrm{C}-\mathrm{H}$ bond insertions. More recently, we performed a more thorough $\mathrm{D}-,{ }^{13} \mathrm{C}$-, and ${ }^{18} \mathrm{O}$-labeling study of the reactions of $\mathrm{Fe}(\mathrm{CO})_{2}^{-}$with methanol which clearly disclosed the occurrence of three competing reactions involving the loss of $\mathrm{CO}, \mathrm{H}_{2}$ or two $\mathrm{H}_{2}$ molecules from the collision complex [13].

Relatively few examples of insertions of metal carbonyl anions into carbon-carbon or carbon-oxygen bonds have been reported. A pertinent example is found in the reactions of $\mathrm{Cr}(\mathrm{CO})_{3}^{-}$with simple organic esters and ketones which proceed partly by loss of $\mathrm{CO}$ from the collision complex [14]. This reaction involves, at least in part, extensive bond activation of the ester including carbon-carbon and carbon-oxygen bond insertions as revealed by the occurrence of ${ }^{93} \mathrm{CO}$ loss in the reaction of $\mathrm{Cr}(\mathrm{CO})_{3}^{-}$with the ${ }^{13} \mathrm{C}$-labeled ethyl acetate $\left(\mathrm{CH}_{3}{ }^{13} \mathrm{COOC}_{2} \mathrm{H}_{5}\right)$. The present study was undertaken to gain new insights into the oxidative addition reactions of electronically unsaturated transition metal carbonyl anions, $\left[\mathrm{M}(\mathrm{CO})_{\mathrm{x}}^{-}\right](\mathrm{M}=\mathrm{Cr}, \mathrm{Mn}, \mathrm{Fe}$, $\mathrm{Co}$ ) with organic esters in the gas phase. Methyl formate was chosen as a simple model ester substrate particularly because of its readily available high isotopic purity ${ }^{13} \mathrm{C}$ - and D-labeled analogs which were perceived to be essential for the definition of complex and competing reaction channels in the various ester $/ \mathrm{M}(\mathrm{CO})_{x}^{-}$bimolecular encounters.

\section{Experimental}

\section{Instrumentation}

All experiments were performed by use of Fourier transform ICR (FT-ICR) mass spectrometry [15], employing two single-cell spectrometers and an instrument equipped with an external ion source.

The single-cell FT-ICR mass spectrometer, designed and constructed at the University of Amsterdam [16-18], was used for the experiments with the cobalt anions and the $\mathrm{Fe}(\mathrm{CO})_{3}^{-}$ions. To this end, $\mathrm{Co}(\mathrm{CO})_{3} \mathrm{NO}$ and $\mathrm{Fe}(\mathrm{CO})_{5}$, respectively, and methyl formate were introduced through the heated inlet systems (at ambient temperature) to a total pressure of $\sim 4 \times 10^{-7}$ mbar and a partial pressure of the metal compound of $\sim 1 \times 10^{-7}$ mbar. The ions $\mathrm{Co}(\mathrm{CO})_{2}^{-}, \mathrm{Co}(\mathrm{CO})(\mathrm{NO})^{-}$, $\mathrm{Co}(\mathrm{CO})_{3}^{-}, \mathrm{Co}(\mathrm{CO})_{2}(\mathrm{NO})^{-}$, and $\mathrm{Fe}(\mathrm{CO})_{3}^{-}$were formed by electron ionization (EI) of the corresponding metal compounds, whereas $\mathrm{Co}^{-}, \mathrm{Co}(\mathrm{CO})$, and $\mathrm{Co}(\mathrm{NO})^{-}$ were formed by collision-induced dissociation (CID) of the primary ions. Impact of low kinetic energy electrons on the metal compounds resulted in abundant
$[\mathrm{M}-\mathrm{CO}]^{-}$ions. A possible interference of these ions with the reactions studied was prevented by ejecting the electrons from the ICR cell as outlined elsewhere [19]. The Kensington Bruker Spectrospin CMS-47 (Eällander, Switzerland) has been described previously $[20,21]$. For the experiments with this instrument the neutral precursors, $\mathrm{Cr}(\mathrm{CO})_{6}, \mathrm{Mn}_{2}(\mathrm{CO})_{10}$, and $\mathrm{Fe}(\mathrm{CO})_{5}$, were admitted to the ICR cell from an inlet system through a leak valve maintained slightly above ambient temperature $[22,23]$. The metal compound and methyl formate were introduced in a pressure ratio of about 1:5 and a total indicated pressure of about $3.5 \times$ $10^{-7}$ mbar. Low-energy ionization $(5-10 \mathrm{eV})$ of the metal precursors resulted in the formation of various electron-deficient metal carbonyl anions [23]. Interference of low kinetic energy electrons with the metal precursors, which would result in the reformation of the primary ions $\mathrm{Cr}(\mathrm{CO})_{5}^{-}, \mathrm{Mn}(\mathrm{CO})_{5}^{-}$, and $\mathrm{Fe}(\mathrm{CO})_{4}^{-}$, was prevented by ejection of the secondary electrons prior to the ion-molecule reaction delay [22].

The general operating procedure of the Amsterdam Bruker Spectrospin CMS 47X (Eällander, Switzerland) instrument [24] has been described previously [25, 26]. The $\mathrm{Mn}_{2}(\mathrm{CO})_{10}$ and $\mathrm{Fe}_{2}(\mathrm{CO})_{9}$ compounds were introduced into an external EI source with a heated direct insertion probe (temperature $\sim 50{ }^{\circ} \mathrm{C}$ ). The $\mathrm{Cr}(\mathrm{CO})_{6}$ compound was introduced through a leak valve to a pressure of $7-10 \times 10^{-7}$ mbar as measured by an uncalibrated ionization gauge placed beneath the ionsource housing. Nitrous oxide was used as a moderator gas and admitted to the external ion source to a total pressure of $1-2 \times 10^{-4}$ mbar. Moderation of the ionizing electrons to low kinetic energies is known to enhance the formation of negative ions from the metal carbonyl compound since the cross section for electron capture for most of these compounds is the largest at low electron energies [27]. In this way abundant $\mathrm{Cr}(\mathrm{CO})_{5}^{-}$ions are formed from $\mathrm{Cr}(\mathrm{CO})_{6}, \mathrm{Mn}(\mathrm{CO})_{5}^{-}$ from $\mathrm{Mn}_{2}(\mathrm{CO})_{10}$, and $\mathrm{Fe}(\mathrm{CO})_{4}^{-}$from $\mathrm{Fe}_{2}(\mathrm{CO})_{9}$. In addition, electron impact on $\mathrm{N}_{2} \mathrm{O}$ yields abundant $\mathrm{O}^{-}$. ions, which react with the neutral carbonyl compound by lass of $\mathrm{CO}_{2}$ from the collision complex, thereby enhancing the yield of primary metal carbonyl anion fragments [12, 28]. The primary negative ions were extracted from the ion source, accelerated to energies of about $3 \mathrm{keV}$, and focused by various ion lenses and deflection plates. The ions were subsequently decelerated and trapped in the FT-ICR cell [24]. The voltage applied to the trapping plates of the cell was -1 to -2 V. To generate anions containing fewer carbonyl ligands than the primary ions, the latter ions were subjected to CID $[12,29]$. To achieve this, the primary ions were excited to translational energies of about $35 \mathrm{eV}$ (laboratory frame) followed by admission of argon through a pulsed valve (with a peak pressure of $10^{5}-10^{-4}$ mbar), in order to allow for multiple collisions and subsequent loss of $\mathrm{CO}$ ligands [12]. The product ions were cooled by multiple collisions with another pulse of argon admitted 0.5-1 $\mathrm{s}$ after the first 
pulse, isolated, and allowed to react with methyl formate for 1-5 s. A typical pulse sequence applied in these experiments is given in Figure 1.

In most experiments the indicated pressure of the substrate was about $1 \times 10^{-7}$ mbar as measured by an uncalibrated ionization gauge $[25,26]$ placed near the entrance for admission of the substrates to the main vacuum system.

\section{Materials}

The metal carbonyls and unlabeled methyl formate were high-purity commercial samples obtained from Strem Chemicals (Newburyport, MA) and Aldrich Chemical Co. (Milwaukee, WI) and were used without further purification. The $\mathrm{DCOOCH}_{3}$ (98\% isotopic purity) and $\mathrm{H}^{13} \mathrm{COOCH}_{3}$ (99\% isotopic purity) compounds were obtained from Aldrich Chemicals and Cambridge Isotope Laboratories (Woburn, MA), respectively. The purity and label content of these latter compounds were checked from their (low electronvolt) positive ion mass spectra.

\section{Results}

The results of the reactions of the $\mathrm{M}(\mathrm{CO})_{\pi}^{-}$and $\mathrm{M}^{-}$ $\mathrm{M}=\mathrm{Cr}, \mathrm{Fe}, \mathrm{Co})$ ions with unlabeled methyl formate

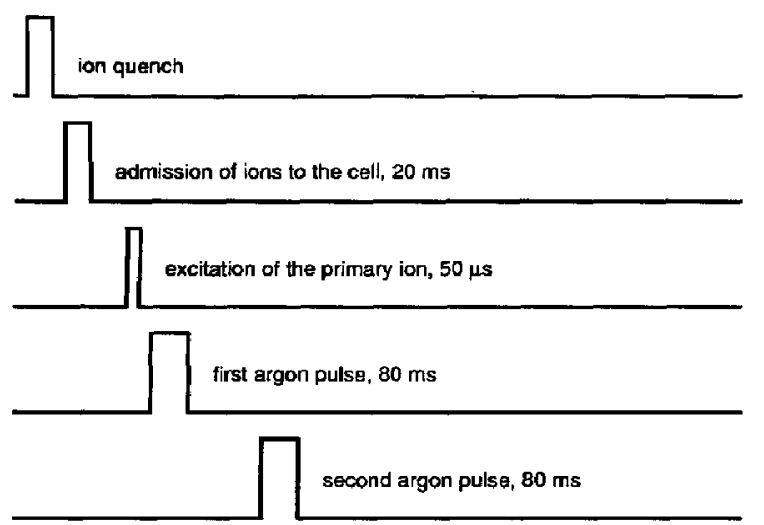

preselection of the ion of interest, $15 \mathrm{~ms}$

reselection of the ian of interest, $400 \mathrm{~ms}$

Figure 1. Pulse sequence for formation, thermalization, and reaction of coordinatively/electronically unsaturated metal carbonyl anions and detection of the product ions formed in their reactions with a given substrate in the CMS 47X FT-ICR mass spectrometer (see text). are given in Table 1. The monocarbonyl anion $\mathrm{Cr}(\mathrm{CO})^{-}$ could not be generated in a sufficient yield $[12,29]$ for its bimolecular reactions with the esters to be studied. The $\mathrm{Mn}^{-}$ion is unstable towards electron detachment as the electron affinity of the manganese atom is negative [30]. In addition to the ions listed, $\mathrm{M}(\mathrm{CO})_{4}^{-}(\mathrm{M}=$ $\mathrm{Cr}, \mathrm{Mn}, \mathrm{Fe})$ and $\mathrm{M}(\mathrm{CO})_{5}^{-}(\mathrm{M}=\mathrm{Cr}$ and $\mathrm{Mn})$ were examined and observed to be unreactive toward methyl formate.

The results given in Table 1 show that only the twoand three-coordinate anions with fewer than 16 valence electrons are reactive towards methyl formate. These ions react predominantly by loss of one or more $\mathrm{CO}$ ligands (eq 2):

$$
\begin{aligned}
\mathrm{M}(\mathrm{CO})_{\times}^{-} & +\mathrm{HCOOCH}_{3} \\
\rightarrow & \left(\mathrm{HCOOCH}_{3}\right) \mathrm{M}(\mathrm{CO})_{\mathbf{x}-n}^{-} \\
& +\mathrm{nCO} \quad(\mathrm{n}=1-3)
\end{aligned}
$$

Certain ions react also under expulsion of other neutral species. For example, the $\mathrm{Cr}(\mathrm{CO})_{3}^{-}$ion reacts with the substrates to a minor extent by loss of an $\mathrm{HCO}^{\circ}$ radical. Loss of a radical from the collision complex is not anomalous for $\mathrm{Cr}(\mathrm{CO})_{3}^{-}$which reacts likewise with other substrates, for example, esters, ethers [14], and methanol [12]. As shown in earlier reports, not only $\mathrm{Cr}(\mathrm{CO})_{3}^{-}$, but also the $\mathrm{Mn}(\mathrm{CO})_{3}^{-}$and $\mathrm{Fe}(\mathrm{CO})_{2}^{-}$ions, are very reactive toward a number of substrates including alkanes [12, 31, 32]. With methyl formate the latter two ions react partly by loss of the elements of $\left[\mathrm{C}, \mathrm{H}_{2}, \mathrm{O}\right]$ and $\mathrm{CH}_{3} \mathrm{OH}$ from the collision complex (eqs 3 and 4) and similar reactions are observed for the $\mathrm{Co}(\mathrm{CO})_{2}^{-}$ion.

$$
\begin{aligned}
\mathrm{M}(\mathrm{CO})_{\mathrm{x}}^{-}+\mathrm{HCOOCH}_{3} \\
\rightarrow\left(\mathrm{CH}_{2} \mathrm{O}\right) \mathrm{M}(\mathrm{CO})_{\mathrm{x}}^{-}+\left[\mathrm{C}, \mathrm{H}_{2}, \mathrm{O}\right] \\
\rightarrow \mathrm{M}(\mathrm{CO})_{\mathrm{x}+1}^{-}+\mathrm{CH}_{3} \mathrm{OH}
\end{aligned}
$$

The relative abundances of the product ions in Table 1 were obtained by measuring the temporal variations of product ion distributions. Occasionally, the relative abundances varied widely with reaction time. For example, for the $\mathrm{Cr}(\mathrm{CO})_{2}^{-}$(11 electrons) and $\mathrm{Mn}(\mathrm{CO})_{2}^{-}$ (12 electrons) ions it was observed that loss of three CO molecules from the collision complex was a relatively pronounced reaction at short times, whereas loss of two CO molecules increased in importance with time. The same behavior was observed with $\mathrm{Co}(\mathrm{CO})(\mathrm{NO})^{-}$(15 electrons) for the loss of two and one $\mathrm{CO}$ molecule(s), respectively. These results strongly suggest the occurrence of an interndl or kinetic energy effect for these reactions. Careful adjustment of the ion-isolation parameters to avoid off-resonance excitation of the reactant ions as much as possible [12, 33] decreased the significance of the expulsion of all available $\mathrm{CO}$ molecules in the experiments with the $\mathrm{Cr}(\mathrm{CO})_{2}^{-}, \mathrm{Mn}(\mathrm{CO})_{2}^{-}$, and $\mathrm{Co}(\mathrm{CO})(\mathrm{NO})^{-}$ions to less 
Table 1. Normalized abundances (\%) of the ionic products formed in the reactions between the metal carbonyl anions and methyl formate ${ }^{a}$

\begin{tabular}{|c|c|c|c|c|}
\hline Ion & No. of Electrons & Product lons & Neutral(s) & Relative Abundance ${ }^{b}$ \\
\hline $\mathrm{Cr}^{-\mathrm{C}}$ & (7) & no reaction & & \\
\hline \multirow{2}{*}{$\mathrm{Cr}(\mathrm{CO})_{2}^{-\mathrm{c}}$} & 11 & $\mathrm{HCr}\left(\mathrm{OCH}_{3}\right)^{-}$ & $3 \mathrm{CO}$ & $<15$ \\
\hline & & $\mathrm{HCr}(\mathrm{CO})\left(\mathrm{OCH}_{3}\right)^{-}$ & $2 \mathrm{CO}$ & $>85$ \\
\hline \multirow[t]{2}{*}{$\mathrm{Cr}(\mathrm{CO})_{3}^{-\mathrm{d}}$} & 13 & $\mathrm{HCr}\left(\mathrm{CO}_{2}\left(\mathrm{OCH}_{3}\right)^{-}\right.$ & $2 \mathrm{co}$ & 95 \\
\hline & & $\mathrm{Cr}(\mathrm{CO})_{3}\left(\mathrm{OCH}_{3}\right)^{-}$ & $\mathrm{HCO}$ & 5 \\
\hline $\mathrm{Mn}(\mathrm{CO})^{-\mathrm{c}}$ & 10 & no reaction & & \\
\hline \multirow[t]{2}{*}{$\mathrm{Mn}(\mathrm{CO})_{2}^{-}$} & 12 & $\mathrm{HMn}\left(\mathrm{OCH}_{3}\right)^{-}$ & $3 \mathrm{CO}$ & $<15$ \\
\hline & & $\mathrm{HMn}(\mathrm{CO})\left(\mathrm{OCH}_{3}\right)^{-}$ & $2 \mathrm{CO}$ & $>85$ \\
\hline \multirow[t]{3}{*}{$\mathrm{Mn}(\mathrm{CO})_{3}^{-d}$} & 14 & $\mathrm{HMn}(\mathrm{CO})_{2}\left(\mathrm{OCH}_{3}\right)^{-}$ & $2 \mathrm{co}$ & 50 \\
\hline & & $\mathrm{Mn}\left(\mathrm{CO}_{4}^{-}\right.$ & $\mathrm{CH}_{3} \mathrm{OH}$ & 10 \\
\hline & & $\mathrm{Mn}\left(\mathrm{CO}_{3}\left(\mathrm{OCH}_{2}\right)^{-}\right.$ & {$\left[\mathrm{C}, \mathrm{H}_{2}, \mathrm{O}\right]^{\mathrm{e}}$} & 40 \\
\hline $\mathrm{Fe}^{-n}$ & (9) & no reaction & & \\
\hline $\mathrm{Fe}(\mathrm{CO})^{-\mathrm{c}}$ & 11 & no reaction & & \\
\hline \multirow[t]{3}{*}{$\mathrm{Fe}(\mathrm{CO})_{2}^{-d}$} & 13 & $\mathrm{HFe}(\mathrm{CO})\left(\mathrm{OCH}_{3}\right)^{-}$ & $2 \mathrm{CO}$ & 30 \\
\hline & & $\mathrm{Fe}(\mathrm{CO})_{3}^{-}$ & $\mathrm{CH}_{3} \mathrm{OH}$ & 20 \\
\hline & & $\mathrm{Fe}(\mathrm{CO})_{2}\left(\mathrm{OCH}_{2}\right)^{-}$ & {$\left[\mathrm{C}, \mathrm{H}_{2}, \mathrm{O}\right]^{\theta}$} & 50 \\
\hline $\mathrm{Fe}(\mathrm{CO})_{3}^{-\mathrm{d}}$ & 15 & $\mathrm{HFe}(\mathrm{CO})_{3}\left(\mathrm{OCH}_{3}\right)^{-}$ & $\mathrm{CO}$ & 100 \\
\hline $\mathrm{Co}^{-1}$ & $(10)$ & no reaction & & \\
\hline $\mathrm{Co}(\mathrm{CO})^{-1}$ & 12 & no reaction & & \\
\hline \multirow[t]{2}{*}{$\mathrm{Co}\left(\mathrm{CO}_{2}^{-}\right.$} & 14 & $\mathrm{Co}(\mathrm{CO})_{3}^{-}$ & $\mathrm{CH}_{3} \mathrm{OH}$ & 30 \\
\hline & & $\mathrm{Co}(\mathrm{CO})_{2}\left(\mathrm{OCH}_{2}\right)^{-}$ & {$\left[\mathrm{C}, \mathrm{H}_{2}, \mathrm{O}\right]^{\mathrm{e}}$} & 70 \\
\hline $\mathrm{Co}\left(\mathrm{CO}_{3}^{-1}\right.$ & 16 & no reaction & & \\
\hline $\mathrm{Co}\left(\mathrm{NO}^{-1}\right.$ & 13 & no reaction & & \\
\hline \multirow[t]{2}{*}{$\mathrm{Co}(\mathrm{CO})(\mathrm{NO})^{-f}$} & 15 & $\mathrm{HCO}(\mathrm{NO})\left(\mathrm{OCH}_{3}\right)^{-}$ & $2 \mathrm{CO}$ & $<15$ \\
\hline & & $\mathrm{HCo}(\mathrm{CO})\left(\mathrm{NO}^{\prime} \mathrm{HOCH}_{3}\right)^{-}$ & $\mathrm{CO}$ & $>85$ \\
\hline $\mathrm{Co}(\mathrm{CO})_{2}(\mathrm{NO})^{-1}$ & 17 & no reaction & & \\
\hline
\end{tabular}

a see text.

h The accuracy has been estimated to be about $15 \%$.

Experiment performed with the CMS 47X FT-ICR spectrometer; see Experimental section.

Studied with the CMS 47 FT-ICR instrument; see Experimental section.

- Indicates the loss of the elements of $\mathrm{C}, \mathrm{H}_{2}$, and $\mathrm{O}$; see text.

Measured with the FT-ICR spectrometer designed and constructed at the University of Amsterdam: see Experimental section.

than $15 \%$ (see Table 1). This dependence may reflect that the bonding energies of the last $\mathrm{CO}$ molecule are relatively low for the intermediate species. Therefore, in these cases relative product ion abundances are obtained only at relatively long reaction times $(>50 \%$ conversion into products). A similar effect was observed in previous experiments for the reaction of $\mathrm{Cr}(\mathrm{CO})_{2}^{-}$and $\mathrm{Mn}(\mathrm{CO})_{2}^{-}$with water [12].

In some experiments performed with the single-cell FT-ICR spectrometers the product ions were observed to react relatively fast with the metal-containing precursors present in the cell, whereas no further reactions occur between these ions and methyl formate within the timeframe of the experiments. In these instances the relative product ion abundances were followed as a function of time. Subsequent extrapolation to zero reaction time then yielded the product ion abundances unperturbed by secondary ion-molecule reactions. A graphical representation for the reaction of $\mathrm{Fe}(\mathrm{CO})_{2}^{-}$with methyl formate as a function of time is given in Figure 2a. The $\mathrm{Fe}(\mathrm{CO})_{3}^{-}$ion formed in this reaction is found to react slowly with the metal-containing precursor present in the cell, whereas no product from the reaction with methyl formate is observed within the timeframe of this particular experiment (see below).

To establish the origin of the atoms incorporated in the neutral products of a reaction, strategic labeling of the substrates with stable isotopes is essential. For example, the reactions of the various metal carbonyl anions with unlabeled methyl formate in which $\mathrm{CO}$ molecules are expelled at first may be regarded as simple ligand exchange reactions. With $\mathrm{H}^{13} \mathrm{COOCH}_{3}$ as a substrate, however, the picture changes completely. In the reaction of various metal carbonyl anions with this substrate, not only unlabeled carbon 

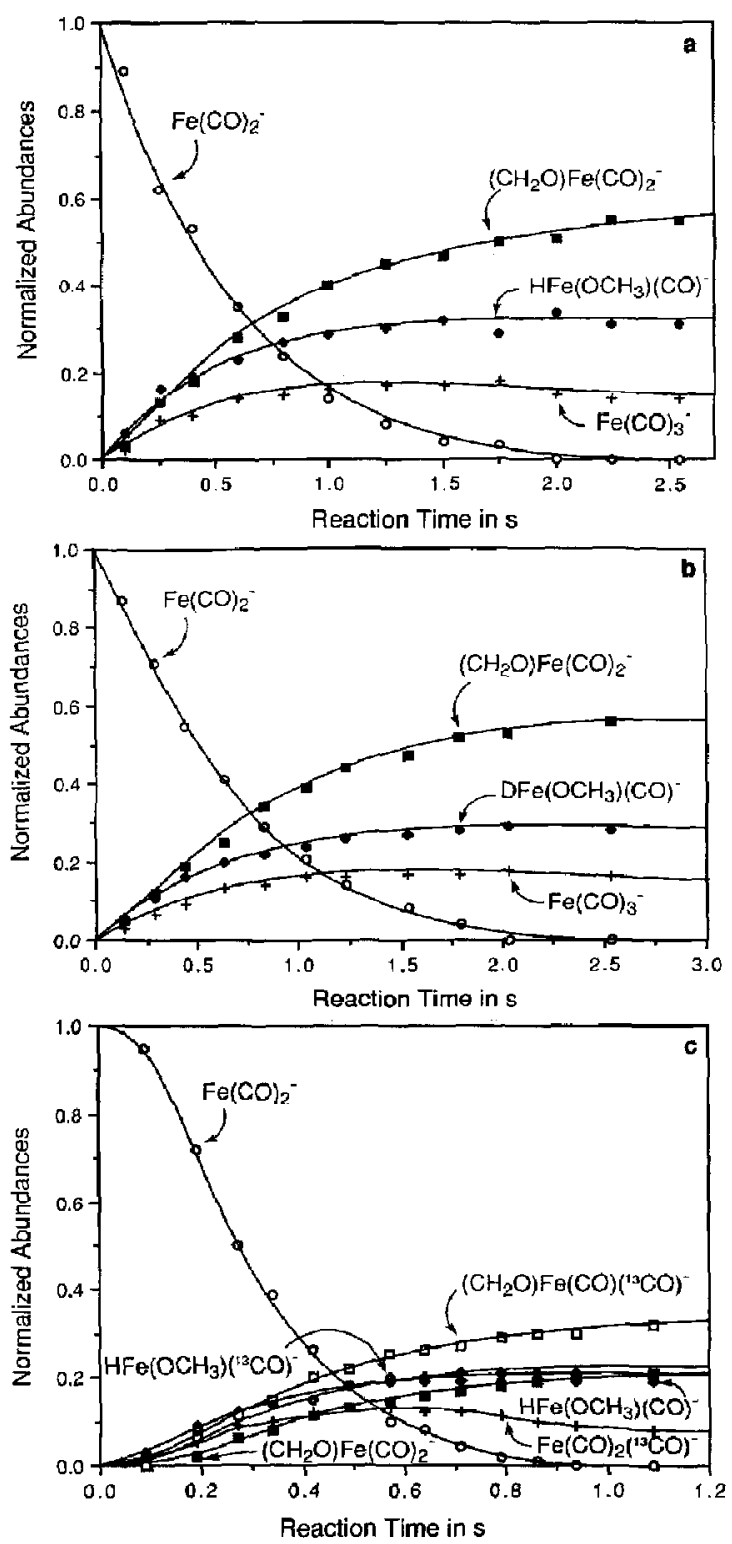

Figure 2. Temporal variations of ion abundances for the reaction of $\mathrm{Fe}(\mathrm{CO})_{2}^{-}$with (a) methyl formate, (b) $\mathrm{DCOOCH}_{3}$, and (c) $\mathrm{H}^{13} \mathrm{COOCH}_{3}$. Obtained with the CMS $47 \mathrm{FI}-\mathrm{ICR}$ spectrometer (see Experimental).

monoxide, but also ${ }^{13} \mathrm{C}$-labeled ligand molecules are eliminated (eq 5 and Table 2):

$$
\begin{aligned}
\mathrm{M}(\mathrm{CO})_{x}^{-} & +\mathrm{H}^{13} \mathrm{COOCH}_{3} \\
& \rightarrow \mathrm{HM}(\mathrm{CO})_{x-n}\left(\mathrm{OCH}_{3}\right)^{-}+\mathrm{nCO}+{ }^{13} \mathrm{CO} \\
& \rightarrow \mathrm{HM}(\mathrm{CO})_{x-n-1}\left({ }^{13} \mathrm{CO}\right)\left(\mathrm{OCH}_{3}\right)^{-}+(\mathrm{n}+1) \mathrm{CO}
\end{aligned}
$$

$$
(\mathrm{n}=0,1,2)
$$

The ${ }^{13} \mathrm{C}$-labeling also reveals that the carbon atom of the eliminated $\left[\mathrm{C}_{1} \mathrm{H}_{2}, \mathrm{O}\right]$ neutral species originates predominantly from the carbonyl group of the ester (eq 6):

$$
\begin{aligned}
\mathrm{M}(\mathrm{CO})_{\mathrm{x}}^{-} & +\mathrm{H}^{13} \mathrm{COOCH}_{3} \\
\rightarrow & \left(\mathrm{CH}_{2} \mathrm{O}\right) \mathrm{M}(\mathrm{CO})_{\mathrm{x}}^{-}+\left[{ }^{13} \mathrm{C}, \mathrm{H}_{2}, \mathrm{O}\right] \\
\rightarrow & \left(\mathrm{CH}_{2} \mathrm{O}\right) \mathrm{M}(\mathrm{CO})_{x-1}\left({ }^{13} \mathrm{CO}\right)^{-}+\left[\mathrm{C}, \mathrm{H}_{2}, \mathrm{O}\right] \\
& (\mathrm{M}=\mathrm{Mn}: \mathrm{x}=3 ; \mathrm{M}=\mathrm{Fe}, \mathrm{Co}: \mathrm{x}=2)
\end{aligned}
$$

The $\left[\mathrm{C}_{1} \mathrm{H}_{2}, \mathrm{O}\right]$ species lost, furthermore, consist of the formyl hydrogen atom and one of the hydrogen atoms in the methyl group as revealed by the reaction with $\mathrm{DCOOCH}_{3}$ in which only $[\mathrm{C}, \mathrm{D}, \mathrm{H}, \mathrm{O}]$ is expelled as shown in eq 7 and illustrated in Figure $2 b$ for the $\mathrm{Fe}(\mathrm{CO})_{2}^{-}$ion.

$$
\begin{aligned}
\mathrm{M}(\mathrm{CO})_{\mathrm{x}}^{-}+\mathrm{DCOOCH}_{3} & \\
& \rightarrow\left(\mathrm{CH}_{2} \mathrm{O}\right) \mathrm{M}(\mathrm{CO})_{x}^{-}+[\mathrm{C}, \mathrm{D}, \mathrm{H}, \mathrm{O}] \\
(\mathrm{M} & =\mathrm{Mn}: \mathrm{x}=3 ; \mathrm{M}=\mathrm{Fe}, \mathrm{Co}: \mathrm{x}=2)
\end{aligned}
$$

Loss of methanol appears to be a relatively simple process in the reaction of $\mathrm{Mn}(\mathrm{CO})_{3}^{-}, \mathrm{Fe}(\mathrm{CO})_{2}^{-}$, and $\mathrm{Co}(\mathrm{CO})_{2}^{-}$with $\mathrm{H}^{13} \mathrm{COOCH}_{3}$ which indicates that this neutral species consists of the methoxy group and the formyl hydrogen atom of the substrate (eq 8 ):

$$
\begin{aligned}
& \mathrm{M}(\mathrm{CO})_{x}^{-}+\mathrm{H}^{13} \mathrm{COOCH}_{3} \\
& \left.\quad \rightarrow \mathrm{M}(\mathrm{CO})_{\times} \times{ }^{13} \mathrm{CO}\right)^{-}+\mathrm{CH}_{3} \mathrm{OH} \\
& (\mathrm{M}=\mathrm{Mn}: \mathrm{x}=3 ; \mathrm{M}=\mathrm{Fe}, \mathrm{Co}: \mathrm{x}=2)
\end{aligned}
$$

Representative time-plots for reactions of $\mathrm{Fe}(\mathrm{CO})_{2}^{-}$, $\mathrm{Cr}(\mathrm{CO})_{3}^{-}$, and $\mathrm{Mn}(\mathrm{CO})_{3}^{-}$with $\mathrm{H}^{13} \mathrm{COOCH}_{3}$ are given in Figures $2 c, 3$, and 4 , respectively. In addition, use of $\mathrm{H}^{13} \mathrm{COOCH}_{3}$ also demonstrates the occurrence of a unique reaction between the $\mathrm{Fe}(\mathrm{CO})_{3}^{-}$ion and methyl formate. This reaction involves relatively fast consecutive exchange of $\mathrm{CO}$ ligands for the methyl formate carbonyl group (eq 9):

$$
\begin{aligned}
& \mathrm{Fe}(\mathrm{CO})_{3}^{-}+\mathrm{H}^{13} \mathrm{COOCH}_{3} \\
& \rightarrow \mathrm{Fe}(\mathrm{CO})_{2}\left({ }^{13} \mathrm{CO}\right)^{-}+\left[\mathrm{C}_{2}, \mathrm{H}_{4}, \mathrm{O}_{2}\right]
\end{aligned}
$$

The time-plot for the consecutive exchange of all $\mathrm{CO}$ ligands for ${ }^{13} \mathrm{CO}$ is given in Figure 5. Expulsion of a carbon monoxide molecule from the collision complex is relatively slow, as indicated by the initial relative abundances of the product ions of carbon monoxide loss and the Fe(CO) ${ }_{2}\left({ }^{13} \mathrm{CO}\right)^{-}$ion for this reaction $(\mathrm{Ta}$ ble 2). Ultimately, all $\mathrm{Fe}(\mathrm{CO})_{3-\mathrm{n}}\left({ }^{13} \mathrm{CO}\right)_{\mathrm{n}}^{-}(\mathrm{n}=0-3)$ ions react to form $\mathrm{HFe}\left(\mathrm{OCII}{ }_{3}\right)(\mathrm{CO})_{3-n}\left({ }^{13} \mathrm{CO}\right)_{n}^{-}\left(\mathrm{n}=0^{-3}\right)$, 
Table 2. Normalized abundances $(\%)$ of the ionic products formed in the reactions between the metal carbonyl anions and $\mathrm{H}^{13} \mathrm{COOCH}_{3} \mathrm{a}_{r} \mathrm{~b}$

\begin{tabular}{|c|c|c|c|}
\hline lon & Product lons & Neutral(s) & Rel. Abundance ${ }^{a, b}$ \\
\hline \multirow[t]{3}{*}{$\overline{\mathrm{Cr}(\mathrm{CO})_{2}^{-\mathrm{c}}}$} & $\mathrm{HCr}\left(\mathrm{OCH}_{3}\right)^{-}$ & $2 \mathrm{CO}+{ }^{13} \mathrm{CO}$ & 15 \\
\hline & $\mathrm{HCr}\left(\mathrm{CO} \mathrm{OOCH}_{3}\right)^{-}$ & $\mathrm{CO}+{ }^{13} \mathrm{CO}$ & 55 \\
\hline & $\mathrm{HCr}\left({ }^{13} \mathrm{CO}\left(\mathrm{OCH}_{3}\right)^{-}\right.$ & $2 \mathrm{CO}$ & 30 \\
\hline \multirow[t]{3}{*}{$\mathrm{Cr}\langle\mathrm{CO})_{3}^{-\mathrm{d}}$} & $\mathrm{HCr}\left(\mathrm{CO}_{2}\left(\mathrm{OCH}_{3}\right)^{-}\right.$ & $\mathrm{CO}+{ }^{13} \mathrm{CO}$ & 50 \\
\hline & $\mathrm{HCr}\left(\mathrm{CON}^{13} \mathrm{CO}\left(\mathrm{OCH}_{3}\right)^{-}\right.$ & $2 \mathrm{CO}$ & 45 \\
\hline & $\mathrm{Cr}(\mathrm{CO})_{3}\left(\mathrm{OCH}_{3}\right)^{-}$ & $\mathrm{H}^{13} \mathrm{CO}$ & 5 \\
\hline \multirow[t]{3}{*}{$\operatorname{Mn}\left(\mathrm{CO}_{2}^{-8}\right.$} & $\mathrm{HMn}\left(\mathrm{OCH}_{3}\right)^{-}$ & $2 \mathrm{co}+{ }^{13} \mathrm{CO}$ & 15 \\
\hline & $\mathrm{HMn}(\mathrm{CO})\left(\mathrm{OCH}_{3}\right)^{-}$ & $\mathrm{CO}+{ }^{13} \mathrm{CO}$ & 55 \\
\hline & $\mathrm{HMn(}{ }^{13} \mathrm{CO}\left(\mathrm{OCH}_{3}\right)^{-}$ & $2 \mathrm{CO}$ & 30 \\
\hline \multirow[t]{5}{*}{$\mathrm{Mn}(\mathrm{CO})_{3}^{-0, d}$} & $\mathrm{HMn}\left(\mathrm{CO}_{2}\left(\mathrm{OCH}_{3}\right)^{-}\right.$ & $\mathrm{CO}+{ }^{13} \mathrm{CO}$ & 23 \\
\hline & $\left.\mathrm{HMn}(\mathrm{CO})^{13} \mathrm{CONOCH}_{3}\right)^{-}$ & $2 \mathrm{CO}$ & 25 \\
\hline & $\mathrm{Mr}\langle\mathrm{CO})_{3}\left({ }^{13} \mathrm{CO}\right)^{-}$ & $\mathrm{CH}_{3} \mathrm{OH}$ & 10 \\
\hline & $\mathrm{Mn}\left(\mathrm{CO}_{3}\left(\mathrm{OCH}_{2}\right)^{-}\right.$ & {$\left[{ }^{13} \mathrm{C}, \mathrm{H}_{2}, \mathrm{O}\right]^{\mathrm{b}}$} & 12 \\
\hline & $\mathrm{Mn}(\mathrm{CO})_{2}\left({ }^{13} \mathrm{COKOCH}_{2}\right)^{-}$ & {$\left[\mathrm{C}, \mathrm{H}_{2}, \mathrm{O}\right]^{\mathrm{b}}$} & 30 \\
\hline \multirow[t]{5}{*}{$\mathrm{Fe}(\mathrm{CO})_{2}^{-\mathrm{d}}$} & $\mathrm{HFe}(\mathrm{CO})\left(\mathrm{OCH}_{3}\right)^{-}$ & $\mathrm{CO}+{ }^{13} \mathrm{Co}$ & 21 \\
\hline & $\mathrm{HFe}\left({ }^{13} \mathrm{CO}\right)\left(\mathrm{OCH}_{3}\right)^{-}$ & $2 \mathrm{CO}$ & 22 \\
\hline & $\mathrm{Fe}(\mathrm{CO})_{2}\left({ }^{13} \mathrm{CO}\right)^{-}$ & $\mathrm{CH}_{3} \mathrm{OH}$ & 15 \\
\hline & $\mathrm{Fe}(\mathrm{CO})_{2}\left(\mathrm{OCH}_{2}\right)$ & {$\left[{ }^{13} \mathrm{C}, \mathrm{H}_{2}, \mathrm{O}\right]^{\mathrm{b}}$} & 15 \\
\hline & $\mathrm{Fe}(\mathrm{CO})\left(^{13} \mathrm{CO}\right)\left(\mathrm{OCH}_{2}\right)$ & {$\left[\mathrm{C}, \mathrm{H}_{2}, \mathrm{O}\right]^{\mathrm{b}}$} & 27 \\
\hline \multirow[t]{3}{*}{$\mathrm{Fe}(\mathrm{CO})_{3}^{-}$} & $\mathrm{Fe}(\mathrm{CO})_{2}\left({ }^{13} \mathrm{CO}\right)^{-}$ & $\mathrm{HCOOCH}_{3}$ & 65 \\
\hline & $\mathrm{HFelCO})_{3}\left(\mathrm{OCH}_{3}\right)^{-}$ & ${ }^{13} \mathrm{CO}$ & 9 \\
\hline & $\mathrm{HFe}\left(\mathrm{COl}_{2}\left(^{13} \mathrm{CO}\right)\left(\mathrm{OCH}_{3}\right)^{-}\right.$ & $\mathrm{co}$ & 26 \\
\hline \multirow[t]{3}{*}{$\mathrm{Co}(\mathrm{CO})_{2}^{-\mathrm{e}}$} & $\mathrm{Co}(\mathrm{CO})_{2}\left({ }^{13} \mathrm{CO}\right)^{-}$ & $\mathrm{CH}_{3} \mathrm{OH}$ & 30 \\
\hline & $\mathrm{Co}\left(\mathrm{CO}_{2}\left(\mathrm{OCH}_{2}\right)^{-}\right.$ & {$\left[{ }^{13} \mathrm{C}, \mathrm{H}_{2}, \mathrm{O}\right]^{\mathrm{b}}$} & 35 \\
\hline & $\mathrm{Co}(\mathrm{CO})\left({ }^{13} \mathrm{CO}\right)\left(\mathrm{OCH}_{2}\right)^{-}$ & {$\left[\mathrm{C}, \mathrm{H}_{2}, \mathrm{O}\right]^{\mathrm{b}}$} & 35 \\
\hline \multirow[t]{3}{*}{$\operatorname{Col} \operatorname{CO}(N O)^{-\theta}$} & $\mathrm{HCO}(\mathrm{NO})\left(\mathrm{OCH}_{3}\right)^{-}$ & $\mathrm{CO}+{ }^{13} \mathrm{Co}$ & 15 \\
\hline & $\mathrm{HCo}(\mathrm{CO})(\mathrm{NO})\left(\mathrm{OCH}_{3}\right)^{-}$ & ${ }^{13} \mathrm{CO}$ & 25 \\
\hline & $\mathrm{HCo}\left({ }^{13} \mathrm{CO}\left(\mathrm{NO}\left(\mathrm{OCH}_{3}\right)^{-}\right.\right.$ & $\mathrm{co}$ & 60 \\
\hline
\end{tabular}

\footnotetext{
Obtained as discussed in the text.

' See Table 1.

'Experiment performed with the CMS $47 \times$ FT-ICR spectrometer; see Experimental section.

'Studied with the CMS 47 FT-ICR instrument; see Experimental section.

a Measured with the FT . ICR spectrometer designed and constructed at the University of Amsterdam; see Experimental section.
}

as exemplified for the reaction with $\mathrm{Fe}(\mathrm{CO})\left({ }^{13} \mathrm{CO}\right)_{2}^{-}(\mathrm{eq}$ 10):

$$
\begin{aligned}
\mathrm{Fe}(\mathrm{CO}) & \left({ }^{13} \mathrm{CO}\right)_{2}^{-}+\mathrm{H}^{13} \mathrm{COOCH}_{3} \\
& \rightarrow \mathrm{HFe}\left(\mathrm{OCH}_{3}\right)(\mathrm{CO})\left({ }^{13} \mathrm{CO}\right)_{2}^{-}+{ }^{13} \mathrm{CO} \\
& \rightarrow \text { HFe }\left(\mathrm{OCH}_{3}\right)\left({ }^{13} \mathrm{CO}_{3}^{-}+\mathrm{CO}\right.
\end{aligned}
$$

\section{Discussion}

Only the two- and three-coordinate metal carbonyl anions with fewer than 16 valence electrons are reac- tive towards methyl formate in the gas phase. This is in line wilh earlier experiments, which demonstrated that metal monocarbonyl anions as well as tetracarbonyl and pentacarbonyl anions are unreactive towards methanol, water, and n-heplane [12]. The only exceptions are the $\mathrm{Fe}(\mathrm{CO})^{-}$ion which reacts slowly with water with the expulsion of $\mathrm{CO}[12]$ and the $\mathrm{V}(\mathrm{CO})_{5}^{-}$ion which is reported to react with methanol [34]. In the present study the general trend in reactivity of metal carbonyl anions observed previously [12] is confirmed qualitatively with methyl formate. The most diverse reactions with this substrate are seen also for the ions $\mathrm{Cr}(\mathrm{CO})_{3}^{-}$(13 valence electrons), $\mathrm{Mn}(\mathrm{CO})_{3}^{-}$ (14 electrons), and $\mathrm{Fe}(\mathrm{CO})_{2}^{-}$(13 electrons). The 


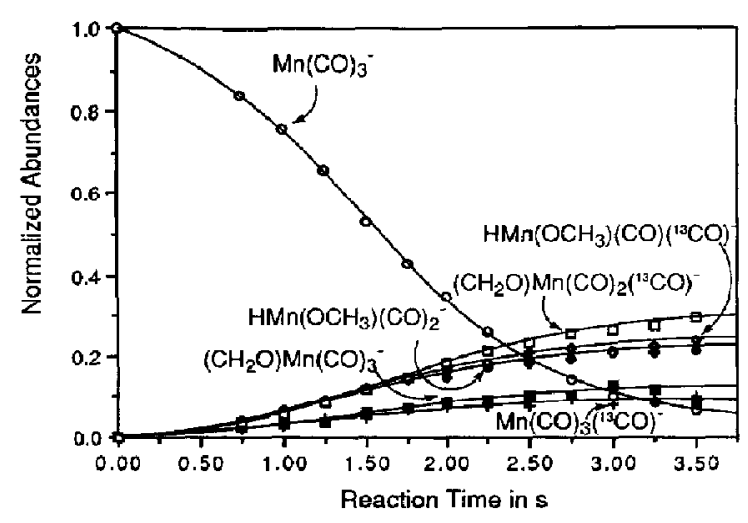

Figure 3. Temporal variations of ion abundances for the reaction of $\mathrm{Mn}(\mathrm{CO})_{3}^{-}$with $\mathrm{H}^{13} \mathrm{COOCH}_{3}$. Obtained with the CMS 47X FI-ICR spectrometer (see Experimental).

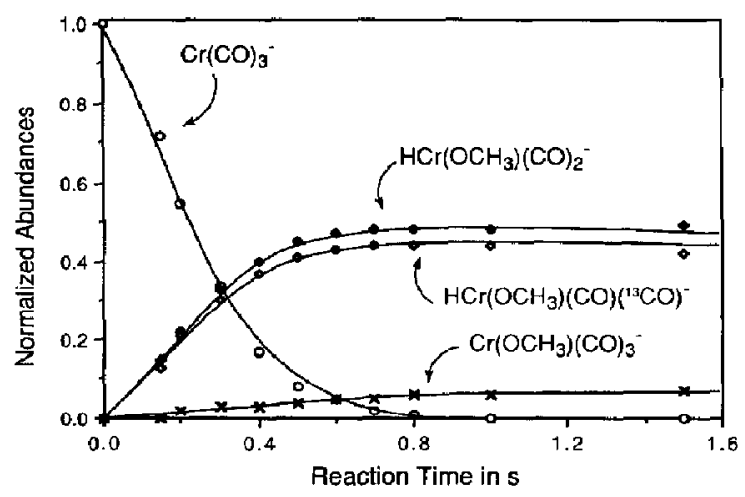

Figure 4. Temporal variations of ion abundances for the reaction of $\mathrm{Cr}(\mathrm{CO})_{3}^{-1}$ with $\mathrm{H}^{13} \mathrm{COOCH}_{3}$. Obtained with the CMS 47 FT-ICR spectrometer (see Experimental).

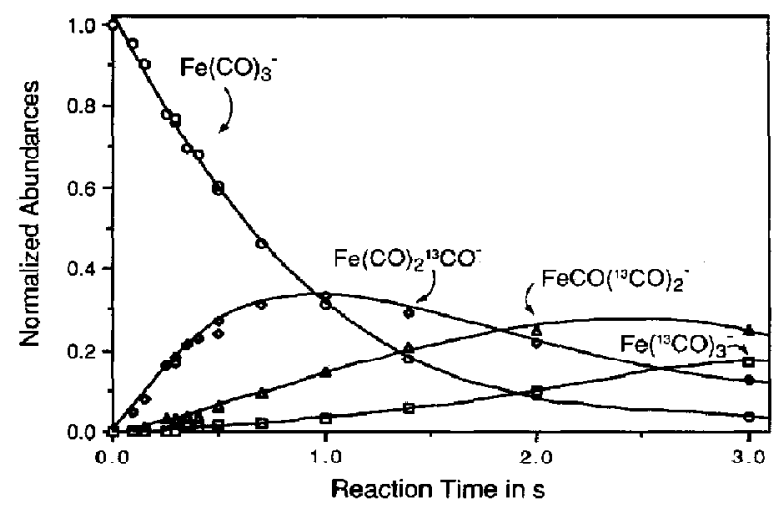

Figure 5. Temporal variations of ion abundances of $\mathrm{Fe}(\mathrm{CO})_{3-n}\left({ }^{13} \mathrm{CO}\right)_{n}^{-}(\mathrm{n}=0-3)$ for the reaction of $\mathrm{Fe}(\mathrm{CO})_{3}^{-}$with $\mathrm{H}^{13} \mathrm{COOCH}_{3}$. The $\mathrm{HFe}\left(\mathrm{OCH}_{3}\right)(\mathrm{CO})_{3-n}\left({ }^{13} \mathrm{CO}\right)_{n}^{-}(\mathrm{n}=0-3)$ product ions have been omitted for clarity. Obtained with the FT-ICR spectrometer constructed at the University of Amsterdam (see Experimental).
$\mathrm{Co}(\mathrm{CO})_{2}^{-}$ion (14 electrons) continues this trend, although $\mathrm{CO}$ ligands are not expelled from the collision complex. This is consistent with the reaction of this ion with methanol, which involves only the loss of $\mathrm{H}_{2}$ [10].

The reactions of several nucleophiles such as alkoxides and carbanions with methyl formate have been discussed in previous reports [35-37]. The main reactions of these anions are proton abstraction, $\mathrm{S}_{\mathrm{N}} 2, \mathrm{~B}_{\mathrm{AC}} 2$, and o-elimination reactions. However, the metal carbonyl anions display a different reactivity towards methyl formate in keeping with other studies which have indicated that negative metal carbonyl anions are very poor nucleophiles [38] and bases [39, 40] in the gas phase.

\section{Loss of $\mathrm{CO}$}

The loss of carbon monoxide molecules from a collision complex is the most pronounced reaction for most of the metal carbonyl anions. Although one might expect this reaction to involve a simple ligand exchange, more thorough investigation with $\mathrm{H}^{13} \mathrm{COOCH}_{3}$ proves that extensive bond activation takes place prior to decarbonylation. Accordingly, the two- and threecoordinate ions may react with methyl formate to form five- or six-coordinate intermediates, respectively, as depicted in Scheme I. These intermediates are probably formed by initial oxidative addition of either the $\mathrm{H}-\mathrm{COOCH}_{3}$ or the $\mathrm{HCO}-\mathrm{OCH}_{3}$ bond of the substrate to the metal ion followed by a migratory insertion of the metal into the other bond adjacent to the original carbonyl group of the substrate molecule. The formation of five- or six-coordinate intermediates leads to the prediction that in the reactions with the ${ }^{13} \mathrm{C}$ labeled substrate, a statistical ratio for the loss of $\mathrm{CO}$ and ${ }^{13} \mathrm{CO}$ as well as for $2 \mathrm{CO}$ and $\mathrm{CO}+{ }^{13} \mathrm{CO}$ should be obtained (see also Scheme II). The results in Table 3 indicate that for most of the ions studied this is indeed observed. However, there are some deviations from the predicted outcome. In particular, the $\mathrm{Fe}(\mathrm{CO})_{2}^{-}$and $\mathrm{Co}(\mathrm{CO})(\mathrm{NO})^{-}$ions react with $\mathrm{H}^{13} \mathrm{COOCH}_{3}$ to expel much less ${ }^{13} \mathrm{CO}$ than expected. This may mean that, to some extent, a carbon monoxide molecule is lost prior to double insertion of the metal center into bonds adjacent to the carbonyl group of the substrate. Obviously, there is a competition between the second insertion and the loss of one or more carbon monoxide ligands.

In the reaction with $\mathrm{Cr}(\mathrm{CO})_{3}^{-}$loss of labeled carbon monoxide is slightly more pronounced (i.c., in a ratio of 1.1 to 1) than expected from the proposed mechanism. However, this result may be within the limits of experimental error and may be explained by differences in the amplitudes of the excitation pulses employed for the detection of these product ions (see Experimental).

The double insertion process as proposed in Scheme I would result for the $\mathrm{Fe}(\mathrm{CO})_{3}^{-}$ion in an unstable 19-electron intermediate [2]. Although 19-electron 


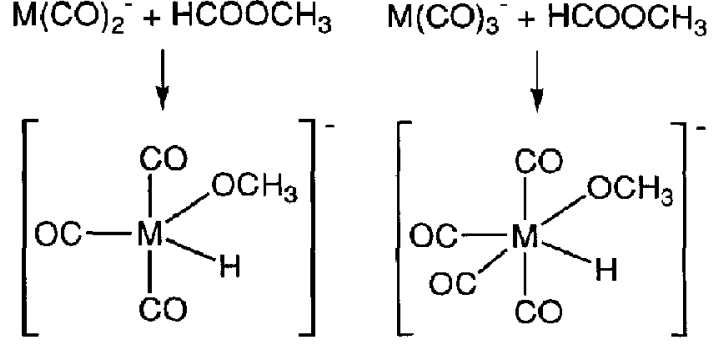

Scheme I. Scheme for the formation of five- and six-coordinate intermediates in the reactions of metal dicarbonyl and tricarbonyl anions, respectively, with methyl formate (see text).

organometallic intermediates have been reported, these species contain ligands capable of accommodating the extra electron [41]. On the other hand, the $\mathrm{Fe}(\mathrm{CO})_{3}^{--}$ion reacts with $\mathrm{H}^{13} \mathrm{COOCH}_{3}$ to expel ${ }^{13} \mathrm{CO}$ and $\mathrm{CO}$ in a ratio of 1:3, as expected from a process in which all $\mathrm{CO}$ ligands become equivalent prior to dissociation. The statistical loss of labeled and unlabeled carbon monoxide in this reaction may indicate that a facile migration of the hydrogen atom of the formyl ligand generated by insertion into the bond between the carbonyl and methoxy group of the substrate can occur prior to dissociation (A fuller discussion of the $\mathrm{Fe}(\mathrm{CO})_{3}^{-} /$ $\mathrm{H}^{13} \mathrm{COOCH}_{3}$ system follows in Exchange of $\mathrm{CO}$ Ligands.) However, for the ions which can undergo the double insertion suggested in Schemes I and II with wut forming intermediates that violate the 18-electron rule, this process leads to electronically more saturated and possibly also more stable intermediates than if insertion occurs only into the $\mathrm{HCO}-\mathrm{OCH}_{3}$ bond.

\section{Loss of $\left[\mathrm{C}, \mathrm{H}_{2}, \mathrm{O}\right]$}

The $\left[\mathrm{C}, \mathrm{H}_{2}, \mathrm{O}\right]$ neutral species lost in the reaction of the $\mathrm{Mn}(\mathrm{CO})_{3}^{-}, \mathrm{Fe}(\mathrm{CO})_{2}^{-}$, and $\mathrm{Co}(\mathrm{CO})_{2}^{-}$ions with methyl formate incorporate the formyl hydrogen and a hydrogen atom from the methoxy group of the substrate as brought about by the sole occurrence of $[C, D, H, O]$ loss

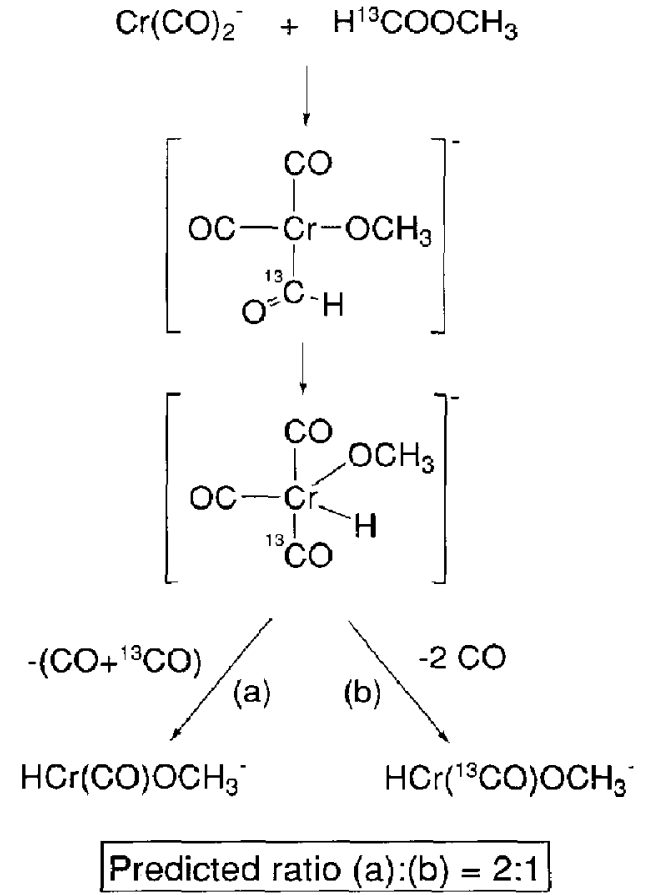

Scheme II. Scheme for the loss of two carbon monoxide molecules in the reaction between $\mathrm{Cr}\left(\mathrm{CO}_{2}^{-}\right.$and $\mathrm{H}^{13} \mathrm{COOCH}_{3}$.

when $\mathrm{DCOOCH}_{3}$ was used as a substrate (eq 7). The exclusive loss of $[\mathrm{C}, \mathrm{D}, \mathrm{H}, \mathrm{O}]$ in these reactions implies also that the carbon and the oxygen atom of the methoxy group are not incorporated in the neutral product(s) of this process. Furthermore, the results of the reactions with the ${ }^{13} \mathrm{C}$-labeled compound show that only part of the neutral species lost contain the carbon atom of the carbonyl group of the substrate (Table 2). The partial expulsion of unlabeled $\left[\mathrm{C}_{1} \mathrm{H}_{2}, \mathrm{O}\right]$ in the reaction of the $\mathrm{Mn}(\mathrm{CO})_{3}^{-}, \mathrm{Fe}(\mathrm{CO})_{2}^{-}$, and $\mathrm{Co}(\mathrm{CO})_{2}^{-}$ ions with $\mathrm{H}^{13} \mathrm{COOCH}_{3}$ indicates therefore that the carbon and oxygen atoms of this particular neutral

Table 3. Relative importance of the losses of unlabeled and ${ }^{1.3} \mathrm{C}$-labeled carbon monoxide from the collision complex formed in the reaction of $\mathrm{M}(\mathrm{CO})_{\times}^{-}$with $\mathrm{H}^{13} \mathrm{COOCH}_{3}{ }^{a} \mathrm{~b}$

\begin{tabular}{llcc}
\hline Ion & \multicolumn{1}{c}{ Loss of } & Ratio Expected & Ratio Found \\
\hline \hline $\mathrm{Cr}(\mathrm{CO})_{2}^{-}$ & $\left(\mathrm{CO}+{ }^{13} \mathrm{CO}\right) / 2 \mathrm{CO}$ & $2 / 1$ & $1.8 / 1^{\mathrm{c}}$ \\
$\mathrm{Cr}(\mathrm{CO})_{3}^{-}$ & $\left(\mathrm{CO}+{ }^{13} \mathrm{CO}\right) / 2 \mathrm{CO}$ & $1 / 1$ & $1.1 / 1^{\mathrm{d}}$ \\
$\mathrm{Mn}(\mathrm{CO})^{-}$ & $\left(\mathrm{CO}+{ }^{13} \mathrm{CO}\right) / 2 \mathrm{CO}$ & $2 / 1$ & $1.8 / 1^{\mathrm{c}}$ \\
$\mathrm{Mn}(\mathrm{CO})_{3}^{-}$ & $1 \mathrm{CO}+{ }^{13} \mathrm{CO} / 2 \mathrm{CO}$ & $1 / 1$ & $1 / 1^{\mathrm{d} d}$ \\
$\mathrm{Fe}(\mathrm{CO})_{2}^{-}$ & $\left(\mathrm{CO}+{ }^{13} \mathrm{CO} / 2 \mathrm{CO}\right.$ & $2 / 1$ & $1 / 1^{\mathrm{d}}$ \\
$\mathrm{Fe}(\mathrm{CO})_{3}^{-}$ & ${ }^{13} \mathrm{CO} / \mathrm{CO}$ & $1 / 3$ & $1 / 3^{\mathrm{d}} \mathrm{e}$ \\
$\mathrm{Co}(\mathrm{CO})(\mathrm{NO})^{-}$ & ${ }^{13} \mathrm{CO} / \mathrm{CO}$ & $1 / 1$ & $0.4 / 1^{\mathrm{e}}$ \\
\hline
\end{tabular}

a See text.

b See Table 2 and Scheme II.

Experiment performed with the CMS 47X FT-ICR spectrometer; see Experimental section.

dStudied with the CMS 47 FT-ICR instrument: see Experimental section.

- Measured with the FT-ICR spectrometer designed and constructed at the University of Amsterdam; see Experimental section. 
product originate from the reactant ion. Based on these findings it is not possible to conclude unequivocally whether this reaction involves the loss of a formaldehyde molecule or $\mathrm{CO}+\mathrm{H}_{2}$. In addition, it is not feasible to distinguish between these possibilities only on the basis of thermochemical data since the $\Delta_{\mathrm{f}} H^{\circ}$ values of $\mathrm{CH}_{2} \mathrm{O}$ and $\mathrm{CO}+\mathrm{H}_{2}$ are almost equal $(-109$ and $-111 \mathrm{~kJ} \mathrm{~mol}^{-1}$, respectively) [42]. The elimination of $\left[\mathrm{C}, \mathrm{H}_{2}, \mathrm{O}\right]$ may involve formation of an intermediate in which the carbonyl group of the substrate and the $\mathrm{CO}$ ligands have become equivalent. The formation of this intermediate will lead to statistical (expected) ratios for the loss of $\left[{ }^{13} \mathrm{C}_{1} \mathrm{H}_{2}, \mathrm{O}\right]$ and $\left[\mathrm{C}, \mathrm{H}_{2}, \mathrm{O}\right]$ as presented in Table 4. However, unlabeled carbon monoxide may be expelled prior to formation of this intermediate, as was observed for some of the decarbonylation reactions (see Loss of $\mathrm{CO}$ ). Taking this into account, we expect the ratio for loss of $\left[{ }^{13} \mathrm{C}_{1} \mathrm{H}_{2}, \mathrm{O}\right]$ and $\left[\mathrm{C}_{1} \mathrm{H}_{2}, \mathrm{O}\right]$ to be $\leq 1 / 3$ if $\mathrm{Mn}(\mathrm{CO})_{3}^{-}$is the reactant ion and $\leq 1 / 2$ in reactions with the metal dicarbonyl anions.

The experimentally obtained ratios for loss of $\left[{ }^{13} \mathrm{C}_{2} \mathrm{H}_{2}, \mathrm{O}\right]$ and $\left[\mathrm{C}_{2} \mathrm{H}_{2}, \mathrm{O}\right]$ for the $\mathrm{Mn}(\mathrm{CO})_{3}^{-}, \mathrm{Fe}(\mathrm{CO})_{2}^{-}$, and $\mathrm{Co}(\mathrm{CO})_{2}^{-}$ions given in Table 4, however, differ considerably from the expected ratios. Significantly, more $\left[{ }^{13} \mathrm{C}, \mathrm{H}_{2}, \mathrm{O}\right]$ is expelled than predicted. This points to the formation of formaldehyde with predominant incorporation of the carbonyl group of the substrate, implying that a five- or six-coordinate intermediate as presented in Scheme I may not be formed in these reactions. With the present results and within the constraints of the thermochemical data, it is not possible to derive a detailed mechanistic scheme for the $\left[\mathrm{C}_{3} \mathrm{H}_{2}, \mathrm{O}\right]$ loss. However, the initial step may be proposed to be insertion in the $\mathrm{HCO}-\mathrm{OCH}_{3}$ bond as illustrated in Scheme III. Following this step, insertion into the $\mathrm{H}-\mathrm{CO}$ bond of the formyl ligand may occur prior to the loss of formaldehyde and/or $\mathrm{CO}+\mathrm{H}_{2}$ as indicated by channels $c_{1}$ and $c_{2}$. In addition, formaldehyde may be formed as shown in channel $d$. In this channel, the formyl group remains intact and forms a formaldehyde molecule with one of the hydrogen atoms from the methoxide ligand. In this respect,

Table 4. Abundance ratios for the product ions of the competing losses of $\left[{ }^{13} \mathrm{C}, \mathrm{H}_{2}, \mathrm{O}\right]$ and $\left[\mathrm{C}, \mathrm{H}_{2}, \mathrm{O}\right]$ in the reactions between metal carbonyl anions and $\mathrm{H}^{13} \mathrm{COOCH}_{3}{ }^{\text {a }}$

\begin{tabular}{lcc}
\hline & $\begin{array}{c}\text { Ratio Expected for Loss of } \\
{\left[{ }^{13} \mathrm{C}, \mathrm{H}_{2}, \mathrm{O}\right] /\left[\mathrm{C}, \mathrm{H}_{2}, \mathrm{O}\right]^{\mathrm{a}}}\end{array}$ & Ratio Found \\
\hline lon & $\leq 1 / 3$ & $1.2 / 3^{\mathrm{b.c}}$ \\
$\mathrm{Mn}(\mathrm{CO})_{3}^{-}$ & $\leq 1 / 2$ & $1.1 / 2^{\mathrm{c}}$ \\
$\mathrm{Fe}(\mathrm{CO})_{2}^{-}$ & $\leq 1 / 2$ & $2 / 2^{\mathrm{d}}$ \\
$\mathrm{CO}(\mathrm{CO})_{2}^{-}$ & & \\
\hline
\end{tabular}

a The $\leq$ sign refers to the formation of carbon monoxide $+\mathrm{H}_{2}$ as discussed in the text.

bexperiment performed with the CMS 47X FT -ICR spectrometer: see Experimental section.

"Obtained with the CMS 47 FT-ICR instrument; see Experimental section.

Measured with the FT-ICR spectrometer designed and constructed at the University of Amsterdam; see Experimental section.

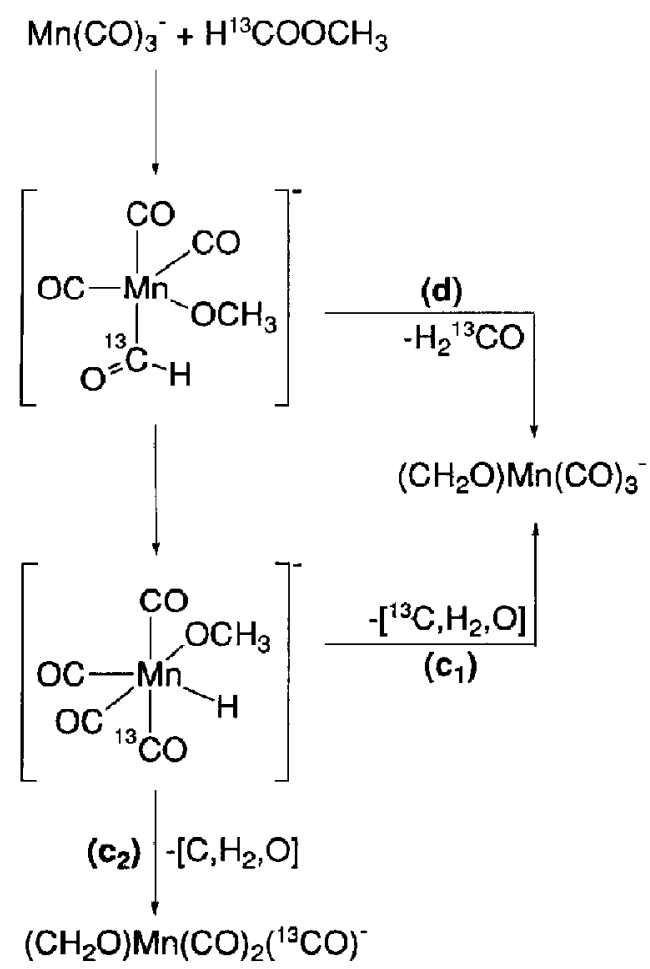

Scheme 11I. Proposed scheme for the competing losses of $\mathrm{H}_{2}{ }^{13} \mathrm{CO},{ }^{13} \mathrm{CO}+\mathrm{H}_{2}$, and $\mathrm{CO}+\mathrm{H}_{2}$ in the reaction between $\mathrm{Mn}(\mathrm{CO})_{3}^{-}$and $\mathrm{H}^{13} \mathrm{COOCH}_{3}$.

it should be noted that the formation of this molecule is unlikely to occur by a conventional reductive elimination of formyl and hydride ligands from the metal center since simple loss of $\mathrm{CH}_{2} \mathrm{O}$ from an $\left(\mathrm{H}^{13} \mathrm{CO}\right) \mathrm{M}(\mathrm{CO})_{x} \mathrm{H}\left(\mathrm{CH}_{2} \mathrm{O}\right)^{-}$intermediate is expected to be kinetically more favorable. This $\mathrm{CH}_{2} \mathrm{O}$ neutral species would contain the carbon and oxygen atoms of the methoxy group of the substrate, which is unlikely in view of the results of the reactions with $\mathrm{DCOOCH}_{3}$ (see above).

Alternatively, initial insertion into the $\mathrm{H}-\mathrm{CH}_{2}$ $\mathrm{OC}(\mathrm{O}) \mathrm{H}$ bond may occur. This is not anomalous for the $\mathrm{Mn}(\mathrm{CO})_{3}^{-}$and $\mathrm{Fe}(\mathrm{CO})_{2}^{-}$ions since initial insertion in a $\mathrm{C}-\mathrm{H}$ bond of a methoxy group has been proposed for reaction of $\mathrm{Mn}(\mathrm{CO})_{3}^{-}$and $\mathrm{Fe}(\mathrm{CO})_{2}^{-}$with methanol [13, 43], and for the $\mathrm{Fe}(\mathrm{CO})_{2}^{-}$ion with dimethyl ether [44]. In addition, $\mathrm{Cr}(\mathrm{CO})_{3}^{-}$[12], $\mathrm{Mn}(\mathrm{CO})_{3}^{-}$, and $\mathrm{Fe}(\mathrm{CO})_{2}^{-}[5,12,31]$ have been observed to activate $\mathrm{C}-\mathrm{H}$ bonds in alkanes. The initial insertion into the $\mathrm{C}-\mathrm{H}$ bond of the methoxy group could be followed by a rearrangement to an intermediate species with an $\mathrm{H}_{2}$ ligand, which then expels $\left[\mathrm{C}, \mathrm{H}_{2}, \mathrm{O}\right]$. Such an intermediate could arise also following initial insertion into the $\mathrm{H}-\mathrm{CO}_{2} \mathrm{CH}_{3}$ bond. The present results do not allow, however, for more detailed discussions of the various mechanistic possibilities for the loss of a $\left[\mathrm{C}_{1} \mathrm{H}_{2}, \mathrm{O}\right]$ neutral species. 


\section{Loss of $\mathrm{CH}_{3} \mathrm{OH}$}

The $\mathrm{Mn}(\mathrm{CO})_{3}^{-}, \mathrm{Fe}(\mathrm{CO})_{2}^{-}$, and $\mathrm{Co}(\mathrm{CO})_{2}^{-}$ions react with methyl formate to expel $\mathrm{CH}_{3} \mathrm{OH}$ in addition to $\left[\mathrm{C}, \mathrm{H}_{2}, \mathrm{O}\right]$ (Table 1). Expulsion of a methanol molecule is considered more likely than consecutive loss of $\left[\mathrm{C}_{1} \mathrm{H}_{2}, \mathrm{O}\right]$ and $\mathrm{H}_{2}$ on the basis of the labeling experiments. These clearly show that the methanol molecule consists of the methoxy group and the formyl hydrogen atom, whereas only one of the hydrogen atoms of the $\left[\mathrm{C}, \mathrm{H}_{2}, \mathrm{O}\right]$ species originates from the methoxy group of the substrate. These results strongly suggest that the loss of methanol proceeds as depicted in Scheme IV. The proposed pathway involves oxidative addition to form a five- or six-coordinate intermediate (Scheme I) followed by reductive elimination of the hydrido and methoxide ligands.

The loss of $\mathrm{CH}_{3} \mathrm{OH}$ results, of course, in addition of a $\mathrm{CO}$ ligand to the reactant ion with concomitant increase in the coordination number of the ion. Addition of a $\mathrm{CO}$ ligand to the reactant ion has been reported also for the reactions of $\mathrm{Cr}(\mathrm{CO})_{3}^{-}$with aldehydes [14], which proceeds in part by alkane elimination. More recently, it has been observed also in the reactions of $\mathrm{Mn}(\mathrm{CO})_{3}^{-}$and $\mathrm{Fe}(\mathrm{CO})_{2}^{-}$with methanol $[12,13]$ in which two hydrogen molecules are expelled from the collision complex and in the reactions of $\mathrm{Fe}(\mathrm{CO})_{2}^{-}$with larger primary alcohols $\left(\mathrm{C}_{n} \mathrm{H}_{2 \mathrm{n}+1} \mathrm{OH}\right.$, $\mathrm{n}=2-6)$ in which $\mathrm{H}_{2}$ and an alkane $\left(\mathrm{C}_{\mathrm{n}-1} \mathrm{H}_{2 \mathrm{n}}\right)$ are eliminated with formation of $\mathrm{Fe}(\mathrm{CO})_{3}^{-}[45]$.

The reactions with methyl formate in which methanol is eliminated are particularly interesting because several homolytic $\mathrm{M}(\mathrm{CO})_{x-1}^{-}-\mathrm{CO}$ bond strengths have been reported $[8,9]$, and as a result, the thermochemistry of this process can be probed. From the heats of formation of $\mathrm{HCOOCH}_{3}, \mathrm{CH}_{3} \mathrm{OH}$, and $\mathrm{CO}$ ( $-356,-202$, and $-111 \mathrm{~kJ} \mathrm{~mol}^{-1}$, respectively) [42] it can be estimated that the reaction enthalpy is negative

$$
\begin{aligned}
& \mathrm{Fe}(\mathrm{CO})_{2}^{-}+\mathrm{H}^{13} \mathrm{COOCH}_{3} \\
& {\left[\begin{array}{l}
\mathrm{CH}_{3} \mathrm{OH} \\
\mathrm{Fe}(\mathrm{CO})_{2}\left({ }^{13} \mathrm{CO}\right)^{-}
\end{array}\right.}
\end{aligned}
$$

Scheme IV. Scheme for the elimination of methanol in the reaction between $\mathrm{Fe}(\mathrm{CO})_{2}^{-}$and $\mathrm{H}^{13} \mathrm{COOCH}_{3}$. or, in other words, this reaction can only proceed if the homolytic bond dissociation energy is more than $44 \mathrm{~kJ}$ $\mathrm{mol}^{-1}$. The reported $\mathrm{CO}$ ligand bond strengths $[8,9]$ are generally in between 135 and $190 \mathrm{~kJ} \mathrm{~mol}^{-1}$, which implies that methanol loss in the reactions of the different metal carbonyl anions with methyl formate is quite exothermic.

\section{Exchange of $\mathrm{CO}$ Ligands}

In the reaction of $\mathrm{Fe}(\mathrm{CO})_{3}^{-}$with urlabeled methyl formate only loss of one $\mathrm{CO}$ molecule is observed. With $\mathrm{H}^{13} \mathrm{COOCH}_{3}$, however, the occurrence of a relatively fast consecutive ligand exchange reaction becomes apparent (Scheme $\mathrm{V}$ and Figure 5). Measurement of the temporal variation of product ion distributions as a function of time and subsequent extrapolation to zero reaction time indicate that the initial ratio for the loss of ${ }^{13} \mathrm{CO} / \mathrm{CO}$ is approximately $1 / 3$ (see Loss of $\mathrm{CO}$ ). Moreover, this ligand exchange reaction is favored over the reaction in which a $\mathrm{CO}$ molecule is eliminated from the collision complex and even complete exchange of all $\mathrm{CO}$ ligands for the labeled carbonyl group of the substrate occurs.

Although the precise mechanism of this unusual ligand exchange reaction is at this juncture not completely clear, some useful insight may be obtained by consideration of the thermochemistry for the formation of various rational neutral species in this reaction. For this purpose, reaction enthalpy changes for some possible neutral species are given in Table 5. From these data, the formation of $2 \mathrm{H}_{2} \mathrm{CO}, 2 \mathrm{H}_{2}+2 \mathrm{CO}$, or $\mathrm{CH}_{3} \mathrm{OH}$ $+\mathrm{CO}$ appears to be endothermic, whereas extensive

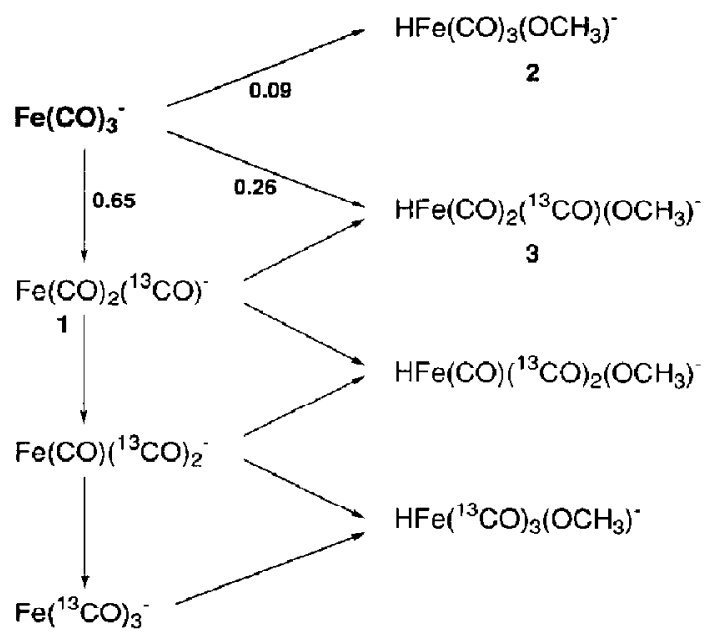

Scheme $\mathrm{V}$. Relationship between the different product ions formed and the channels in the reactions of $\mathrm{Fe}(\mathrm{CO})_{3}^{-}$with $\mathrm{H}^{13} \mathrm{COOCH}_{3}$. The neutral species involved in the reactions have been omitted for clarity. The initial product ion ratios given in the scheme have been abtained by following the product ion distributions as a function of time and extrapolating to zero reaction time. 
Table 5. Enthalpy changes for the loss of $\left[\mathrm{C}_{2}, \mathrm{H}_{4}, \mathrm{O}_{2}\right]$ in the reactions of $\mathrm{Fe}(\mathrm{CO})_{3}^{-}$with $\mathrm{HCOOCH}_{3}$ a

\begin{tabular}{lrlr}
\hline$\left[\mathrm{C}_{2}, \mathrm{H}_{4}, \mathrm{O}_{2}\right]$ & $\begin{array}{c}\Delta_{\mathrm{r}} \mathrm{H}^{\circ} \mathrm{in} \\
\mathrm{kJ} \mathrm{mol}^{-1}\end{array}$ & \multicolumn{1}{c}{$\left[\mathrm{C}_{2}, \mathrm{H}_{4}, \mathrm{O}_{2}\right]$} & $\begin{array}{c}\Delta_{\mathrm{r}} \mathrm{H}^{\circ} \mathrm{in} \\
\mathrm{kJ} \mathrm{mol}^{-1}\end{array}$ \\
\hline \hline $\mathrm{HCOOCH}$ & 0 & $2 \mathrm{H}_{2} \mathrm{CO}$ & +138 \\
$\mathrm{CH}_{3} \mathrm{COOH}$ & -77 & $2 \mathrm{H}_{2}+2 \mathrm{CO}$ & +134 \\
$\mathrm{CH}_{3}+\mathrm{CO}_{2}$ & -113 & $\mathrm{CH}_{3} \mathrm{OH}+\mathrm{CO}$ & +43 \\
\hline
\end{tabular}

apsed on data in ref 42; see text.

rearrangements are required for the formation of $\mathrm{CH}_{3} \mathrm{COOH}$ and $\mathrm{CH}_{4}+\mathrm{CO}_{2}$. A further alternative could involve the expulsion of an unlabeled methyl formate molecule in a thermoneutral reaction. The mechanism of the reaclion is unlikely to involve insertion of the metal into both bonds adjacent to the carbonyl group since this would yield a six-coordinate 19-electron intermediate (Scheme I). However, the reaction mechanism may involve initial oxidative addition of the metal center to the $\mathrm{HCO}-\mathrm{OCH}_{3}$ bond followed by fast migration of a hydrogen atom between different $\mathrm{CO}$ ligands. As a result, all $\mathrm{CO}$ ligands become equivalent before elimination of either an $\mathrm{HCOOCH}_{3}$ or a CO molecule (Scheme VI).

\section{Conclusions}

This study has provided more insight in the extensive bond activation and rearrangements prior to the expulsion of one or more neutral molecules which occur in reactions of coordinatively and electronically unsaturated metal carbonyl anions with methyl formate. The necessity to use strategically $\mathrm{D}$ - and ${ }^{13} \mathrm{C}$-labeled compounds for the elucidation of these reaction channels has been demonstrated.

Of the metal carbonyl ions studied, only the twoand three-coordinate ions with fewer than 16 valence

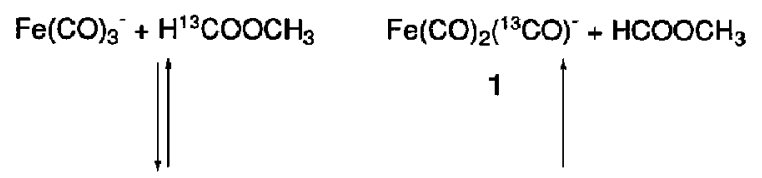

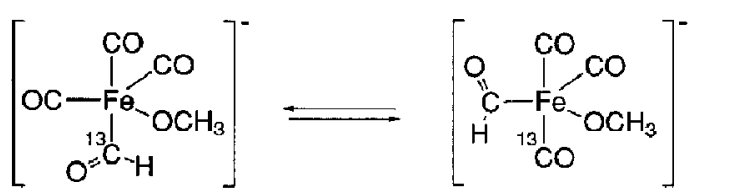

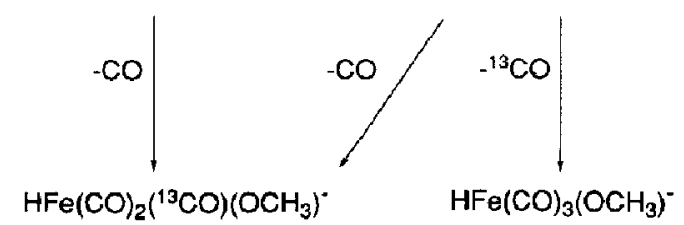

3

2

Scheme VI. Proposed scheme for the carbonyl ligand exchange in the reaction between $\mathrm{Fe}(\mathrm{CO})_{3}^{-}$and $\mathrm{H}^{13} \mathrm{COOCH}_{3}$. The formation of 1 was observed to be relatively fast compared to the formation of 2 and 3 (see text and Table 2). electrons are reactive towards methyl formate in the gas phase. The predominant reaction of the metal carbonyl anions involves insertion of the metal into the bonds adjacent to the $\mathrm{C}=\mathrm{O}$ function of the substrate leading to the formation of a five- or six-coordinate intermediate in which all $\mathrm{CO}$ groups have become equivalent. Expulsion of one or two $\mathrm{CO}$ molecules may ensue subsequently from such relatively coordinatively saturated species.

Additional competing reaction channels are involved in the reactions of $\mathrm{Mn}(\mathrm{CO})_{3}^{-}$(14 metal valence electrons), $\mathrm{Fe}(\mathrm{CO})_{2}^{-}$(13 electrons), and $\mathrm{Co}(\mathrm{CO})_{2}^{-}(14$ electrons) in which also formaldehyde, possibly $\left(\mathrm{H}_{2}+\right.$ $\mathrm{CO})$, and methanol are expelled. One of the hydrogen atoms of the eliminated $\left[\mathrm{C}, \mathrm{H}_{2}, \mathrm{O}\right]$ neutral species originates from the formyl group and the other one from the methoxy group of the substrate. At present, the mechanism for the formation of the $\left[\mathrm{C}, \mathrm{H}_{2}, \mathrm{O}\right]$ neutral species cannot be defined unequivocally, but the elimination of formaldehyde does not involve a reaction channel in which conventional reductive elimination occurs from the metal center.

In addition to the reaction in which one $\mathrm{CO}$ molecule is eliminated from the collision complex, the $\mathrm{Fe}(\mathrm{CO})_{3}^{-}$ ion reacts with methyl formate by subsequent exchange of all $\mathrm{CO}$ ligands for the $\mathrm{C}=\mathrm{O}$ group of methyl formate. As in this latter process another methyl formate is expelled, the reaction must be thermoneutral and probably proceeds by fast migration of hydrogen between different $\mathrm{CO}$ groups in the collision complex. The formation of a six-coordinate 19-electron intermediate in which double insertion of the metal has occurred into the bonds adjacent to the carbonyl group in the substrate is unlikely.

\section{Acknowledgments}

K. J. v. d. B., S. I., and N. M. M. N. thank The Netherlands Organization for Scientific Research (SON/NWO) for continuous support. I. K. G. also thanks the Australian Research Council and DITAC for support.

\section{References}

1. Parshall, G. W. Homogeneous Catalysis; Wiley: New York, 1980.

2. Collman, J. P.; Hegedus, L. S.; Norton, R. S.; Finke, R. G. Principles and Applications of Organotransition Metal Chemistry; University Science Books: Mill Valley, CA, 1987.

3. Eller, K.; Schwarz, H. Chem. Rev. 1991, 91, 1121.

4. Gregor, I. K.; Guilhaus, M. Mass Spectrom. Rev. 1984, 3, 39.

5. Squires, R. R. Chem. Rev. 1987, 87, 623.

6. Martirho Simóes, J. A.; Beauchamp, J. L. Chem. Rev. 1990, 90 , 629.

7. Hop, C. E. C. A.; McMahon, T. B. J. Am. Chem. Soc. 1992, 114, 1237.

8. Sunderlin, L. S.; Wang, D.; Squires, R. R. J. Am. Chem. Soc. 1992, 114, 2788.

9. Sunderlin, L. S.; Wang, D.; Squires, R. R. Proceedings of the 40th American Society for Mass Spectrometry Conference on Mass Spectrometry and Allied Topics; Washington, DC, 1992; p 1051. 
10. McElvany, S. W.; Allison, J. Organometallics 1986, 5, 416.

11. McElvany, S. W.; Allison, J. Organometallics 1986, 5, 1219.

12. van den Berg, K. J.; Ingemann, S.; Nibbering, N. M. M. Org. Mass Spectrom. 1993, 28, 527.

13. van den Berg, K. J.; Ingemann, S.; Nibbering, N. M. M.; Gregor, I. K. Rapid Commun. Mass Spectrom. 1993, 7, 769.

14. Gregor, I. K. Org. Mass Spectrom. 1989, 24, 529.

15. Marshall, A. G.; Verdun, F. R. Fourier Transforms in NMR, Optical and Mass Spectrometry: A User's Handbook; Elsevier: Amsterdam, The Netherlands, 1990; ch. 7.

16. de Koning, L. J.; Kort, C. W. F.; Pinkse, F. A.; Nibbering, N. M. M. Int. J. Mass Spectrom. Ion Processes 1989, 96, 71, and references sited therein.

17. Peerboom, R. A. L.; Ingemann, S.; Nibbering, N. M. M.; Liebman, J. F. J. Chem. Soc. Perkin Trans. 2 1990, 1825, and references cited therein.

18. Nibbering, N. M. M. Rapid Commun. Mass Spectrom. 1993, 7, 747 .

19. Kleingeld, J. C.; Nibbering, N. M. M. Lect. Notes Chem. 1982, 31, 209.

20. Allemann, M.; Kellerhals, Hp.; Wanczek, K.-P. Int. I. Mass Spectrom. Ion Physics 1983, 46, 139.

21. de Koning, L. J.; Fokkens, R. H.; Pinkse, F, A.; Nibbering, N. M. M. Int. I. Mass Spectrom. Ion Processes 1987, 77, 95.

22. Gregor, I. K.; Gregor, R. C. Rapid Commun. Mass Spectrom. $1992,6,221$.

23. Gregor, I. K. Inorg. Chim. Acta 1990, 776, 19.

24. Kofel, $\mathrm{P}_{\text {; }}$ Allemann, M,; Kellerhals, Hp.; Wanczek, K. P. Int. J. Mass Spectrom. Ion Processes 1988, 65, 97.

25. Ingemann, S.; Fokkens, R. H.; Nibbering, N. M. M. J. Org. Chem. 1991, 56, 607.

26. Heck, A. J. R.; Drewello, T.; de Koning, L. J:; Nibbering, N. M. M. Int. J. Mass Spectrom. Ion Processes 1990, 100, 611.

27. Gregor, I. K.; Guilhaus, M. Int. J. Mass Spectrom. Ion Processes $1984,56,167$.
28. VanOrden, S. L.; Buckner, S. W. Polyhedron 1991, 10, 2487.

29. Sallans, L.; Lane, K. R.; Squires, R. R.; Freiser, B. S. J. Am. Chem. Soc. 1985, 107, 4379 .

30. Feigerle, C. S.; Corderman, R. R.; Bobashev, S. V;; Lineberger, W. C. J. Chem. Phys. 1981, 74, 1580.

31. McDonald, R. N.; Jones, M. T.; Chowdhury, A. K. J. Am. Chem. Soc. 1991, 113, 476.

32. McDonald, R. N.; Jones, M. F.; Chowdhury, A. K. I. Am. Chem. Soc. 1992, 114, 71 .

33. Heck, A. J. R.; de Koning, L. J.; Pinkse, F. A.; Nibbering, N. M. M. Rapid Commun. Mass Spectrom. 1991, 5, 406.

34. Buckner, S. W.; VanOrden, S. L. Organometallics 1990, 9, 1093.

35. Johlman, C. L.; Wilkins, C. L. J. Am. Chem. Soc. 1985, 107, 327.

36. DePuy, C. H.; Grabowski, J. J.; Bierbaum, V. M.; Ingemann, S.; Nibbering, N. M. M. I. Am. Chem. Soc. 1985, 107, 1093.

37. van der Wel, H.; Nibbering, N. M. M. Int. J. Mass Spectrom. Ion Processes 1986, 72, 145.

38. Richardson, D. E.; Christ, C. S.; Sharpe, P.; Eyler, J. R. Organometallics 1987, 6, 1819 .

39. Stevens Miller, A, E; Beauchamp, J. L. J, Am. Chem, Soc. 1991, 113, 8765.

40. Stevens Miller, A. E.; Kawamura, A. R.; Miller, T. M. J. Am. Chem. Soc. 1990, 112, 457.

41. Tyler, D. R. Acc. Chem. Res. 1991, 24, 325.

42. Lias, S. G.; Bartmess, J. E.; Liebman, J. F.; Holmes, J. L.; Levin, R. D.; Mallard, W. G. J. Phys. Chem. Ref. Data 1988, 17, Suppl. 1.

43. McDonald, R. N.; Jones, M. T. Organometallics 1987, 6, 1991.

44. McDonald, R. N.; Reed, D. J.; Chowdhury, A. K. Organometallics 1989, $8,1122$.

45. Gregor, I. K.; Gregor, R. C. unpublished results. 